\title{
ANGIOGENIC FACTORS AND CIRCULATING ENDOTHELIAL PROGENITOR CELLS IN PATIENTS WITH TYPE 2 DIABETES MELLITUS
}

Ewelina Drela, Arleta Kulwas, Wiesław Jundziłł, Barbara Ruszkowska-Ciastek, Barbara Góralczyk, Katarzyna Stankowska, Zofia Ruprecht, Jacek Kubica, Danuta Rość

Department of Pathophysiology,

Collegium Medicum in Bydgoszcz, Nicolaus Copernicus University in Torun, Poland 


\section{INTRODUCTION}

- Diabetic foot (DF) is a severe complication of poor controlled diabetes, which may result in nonhealing wounds that lead to lower limb amputation. Impaired angiogenesis seems to play an important role in nonhealing ulceration development.

- VEGF-A and FGF-2 coordinate angiogenesis during healing process. In clinical experiments, these factors are also a potent therapeutic agent in patients with chronic diabetic ulcers. EPCs has brought the new insight into angiogenesis and therapy.

- Therefore, the aim of the study was to evaluate the number of EPCs, plasma levels of VEGF-A, sVEGF-R2 and FGF-2 in diabetic patients. 


\section{MATERIALS AND METHODS}

- Totally, 75 subjects were enrolled: 45 patients with type 2 diabetes (the study group) and 30 healthy volunteers (the control group). The mean age of the patients was 67.1 years in the study group and 63.3 in the controls. The median duration of T2DM was 12.4 years in the test group.

- Patients were divided into 2 groups: 23 with DF (diabetic foot) and 22 without DF.

- VEGF-A, sVEGF-R2 and FGF-2 plasma concentrations were measured by ELISA.

- The number of EPCs was determined by flow cytometry. 


\section{RESULTS}

Number of circulating EPCs and concentrations of angiogenic factors in the patients with DF, patients without DF and the controls.

\begin{tabular}{|c|c|c|c|c|}
\hline $\begin{array}{l}\text { Parameter } \\
\text { [unit] }\end{array}$ & $\begin{array}{c}\text { Patients with DF } \\
\text { Me[Q1;Q3] } \\
\text { I } n=23\end{array}$ & $\begin{array}{c}\text { Patients without DF } \\
\text { Me[Q1;Q3] } \\
\text { II } n=22\end{array}$ & $\begin{array}{c}\text { The control group } \\
\text { Me[Q1;Q3] } \\
\text { III } n=30\end{array}$ & P value \\
\hline $\begin{array}{l}\text { VEGF-A } \\
{[\mathrm{pg} / \mathrm{ml}]}\end{array}$ & $36,0[13,74 ; 73,95]$ & $79,16[29,56 ; 131,55]$ & $15,06[7,98 ; 27,84]$ & $\begin{array}{l}\text { Ivs } \mid p=0,04 \\
\text { Ivs|| } p=0,01 \\
\text { IIvs|| } p=0,0002\end{array}$ \\
\hline $\begin{array}{l}\text { sVEGF-R2 } \\
{[\mathrm{pg} / \mathrm{ml}]}\end{array}$ & $\begin{array}{l}8930,5 \\
{[8360,0 ; 10356,0]}\end{array}$ & $\begin{array}{l}10099 \\
{[8765,2 ; 10841,5]}\end{array}$ & $\begin{array}{l}10738,75 \\
{[9670,5 ; 11766,0]}\end{array}$ & $\begin{array}{l}\text { Ivsl| } p=0,2 \\
\text { Ivs|| } p=0,007 \\
\text { IIvs|| } p=0,07\end{array}$ \\
\hline 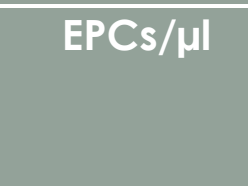 & $\begin{array}{l}0,41 \\
{[0,2 ; 1,22]}\end{array}$ & $\begin{array}{l}0,31 \\
{[0,1 ; 1,53]}\end{array}$ & $\begin{array}{l}0,41 \\
{[0,2 ; 0,92]}\end{array}$ & $\begin{array}{l}\text { Ivs\| } p=0,0581 \\
\text { Ivs||| } p=0,7 \\
\text { I|vs|| } p=0,6\end{array}$ \\
\hline $\begin{array}{c}\text { FGF-2 } \\
{[\mathrm{pg} / \mathrm{ml}]}\end{array}$ & $\begin{array}{l}6,39 \\
{[5,54 ; 8,42]}\end{array}$ & $\begin{array}{l}4,97 \\
{[4,45 ; 6,02]}\end{array}$ & $\begin{array}{l}4,92 \\
{[4,6 ; 5,44]}\end{array}$ & $\begin{array}{l}\text { Ivs\| } p=0,0002 \\
\text { Ivs|l|p=0,000003 } \\
\text { IIvs|| } p=0,8\end{array}$ \\
\hline
\end{tabular}




\section{CONCLUSIONS}

- The study demonstrated that diabetic patients with DF showed decreased VEGF-A and increased FGF-2 levels compared to the patients without DF. It might be associated with impaired angiogenic response.

- This study was supported by grant from National Centre of Science (Poland) based on the decision no. DEC-2011/01/N/NZ5/00293. 


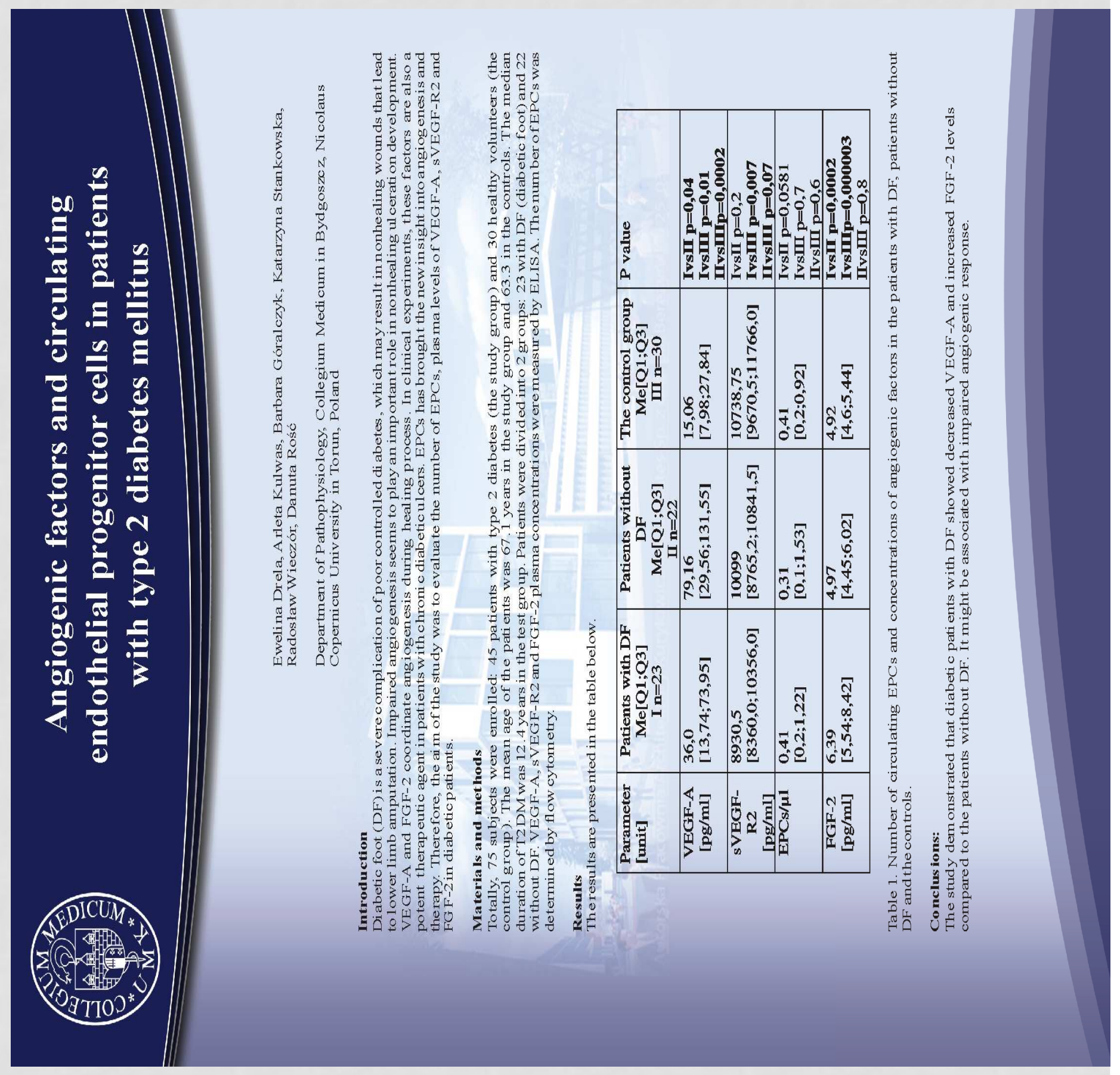

